\title{
THE IMPORT OF HOLLYWOOD FILMS IN CHINA: CENSORSHIP AND QUOTAS
}

\author{
Jessica Grimm
}

CONTENT

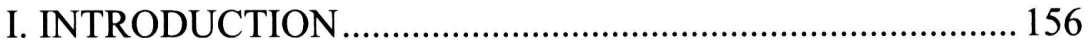

A. What Will Be Examined ................................................. 158

B. State of the Chinese Film Market Today ...................... 159

II. BACKGROUND \& THE SYSTEM AS IT STANDS NOW . 161

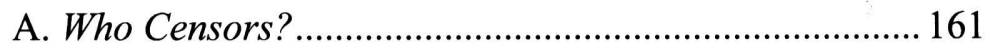

B. Laws and Regulations Governing and Impacting Chinese

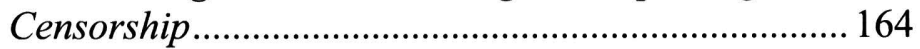

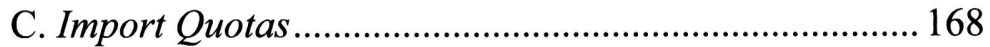

D. Revenue-Sharing ........................................................... 169

III. CASE STUDIES ................................................................. 170

A. Outright Rejection ........................................................ 170

B. Accepted After Adjustments/Self-Censorship ............... 171

C. Accepted and then Later Pulled from Theatres ............ 172

D. Accepted With No Issues ............................................... 174

IV. PROBLEMS WITH THE CURRENT SYSTEM ................. 175

A. Factors that will Predictably Lead to Rejection Based on Past Experience ............................................................. 175

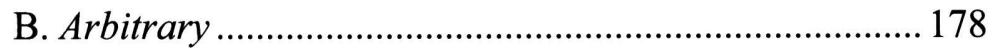

C. Lack of Transparency .................................................... 179

D. Failure to Pay ........................................................... 180

V. WTO RULING \& IMPACT-SHOULD WE PUSH FOR CHINA'S COMPLIANCE? ............................................. 181

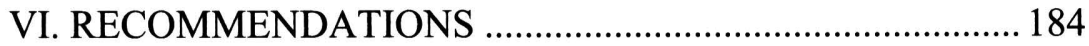

A. Contractual Enforcement/Liquidated Damages............ 184

B. Joint Productions........................................................... 185

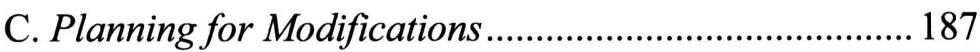




\section{INTRODUCTION}

On May 3, 2013, Marvel Studio's Iron Man 3 opened in United States ("U.S.") theatres, pulling in a domestic total gross of $\$ 409,013,994 .^{\prime}$ In foreign markets, the movie totaled $\$ 806,426,000$, bringing the film's total global gross to $\$ 1,215,439,994 .^{2}$ Of this global total, profits from China accounted for $\$ 121,200,000$, a significant portion of the film's foreign revenue. ${ }^{3}$ Iron Man 3 was neither the first Hollywood film nor the last Hollywood film to be released in China, and it was not even the highest grossing film there. ${ }^{4}$ What is interesting about Iron Man 3, however, is it is one of the most well-known examples of Hollywood adapting, or in this case adding, to the content of a film strictly to make it eligible for release in China.

There are, in fact, four extra minutes of footage in the version released in China, footage that was not present in the domestic and global release. ${ }^{5}$ These four minutes include: (1) product placement for $\mathrm{Gu} \mathrm{Li}$ Duo, a milk drink from an Inner Mongolia-based dairy company; (2) Chinese actress Fan Bingbing playing a nameless assistant to Dr. Wu, the doctor who uses Chinese medicine to help Iron Man; (3) more product placement appearances by two Chinese electronics makers, TCL and Zoomlion; and (4) a shot of cheering, happy Chinese schoolchildren on TV with Iron Man. ${ }^{6}$ While it may seem strange that this extra footage,

1. Iron Man 3, Box OfFICE MOJO, available at www.boxofficemojo.com/movies/?id=ironman 3.htm (last visited Nov. 6, 2015).

2. Id.

3. China All Time Openings, Box OfFICE MoJo, available at http://www.boxofficemojo.com/intl/china/opening/ (last visited Nov. 6, 2015).

4. At the end of 2014, that distinction belonged to Transformers: Age of Extinction, which overtook James Cameron's Avatar and grossed $\$ 222,740,000$ in only ten days. Ben Child, Transformers: Age of Extinction Becomes Highest-Grossing Film of All Time in China, GUARDIAN (July $8, \quad 2014, \quad 7: 17 \quad$ AM), available at http://www.theguardian.com/film/2014/jul/08/transformers-age-extinction-highest-grossingchina (last visited Nov. 6, 2015). The film finally topped out at a total gross of $\$ 320,000,000$. China All Time Openings, supra note 3.

5. Kirsten Acuna, The Biggest Differences In China's Version of 'Iron Man 3', Bus. INSIDER (May 2, 2013, 10:58 AM), available at www.businessinsider.com/chinas-version-ofiron-man-3-2013-5 (last visited Nov. 6, 2015).

6. Id.; Joyce Lau, In China, Iron Man's Muscle is Fed by Inner Mongolian Milk, N.Y. Times (May 2, 2013, 8:44 AM), available at rendezvous.blogs.nytimes.com/2013/05/02/inchina-iron-mans-muscle-is-fed-by-inner-mongolian-milk/?_r=0 (last visited Nov. 6, 2015). 
which did not seem to appeal to Chinese audiences much, was added, there was a rational incentive at its heart. ${ }^{7}$ In the end, it comes down to the profit motive. Hollywood receives a great profit return by tapping into the Chinese market. However, this market presents a unique set of challenges that need to be understood and addressed for Hollywood to fully access it.

The two major issues that will be addressed in this note, in terms of Hollywood's access to the Chinese market, are censorship and quotas. Censorship, here, examines each film's content to determine what must be modified or cut to make the film eligible for screening in China. Quotas, on the other hand, place an absolute limit on film imports, thus making Hollywood's access to the Chinese market highly competitive. Hollywood's access to the Chinese market provides a vast source of revenue for its studios - a benefit to all involved in the industry - and also opens up a new, soft power avenue in U.S.-China relations. Chinese censorship laws have a definite impact on Hollywood studios and a better understanding of them is necessary so the industry can continue to efficiently access the Chinese market. The potential revenue to be gained by accessing the Chinese market is substantial and it is easy to see why Hollywood would want to tap China's potential, especially in light of shrinking domestic movie theatre attendance. ${ }^{8}$ In fact, the 2014 summer alone witnessed a $14.6 \%$ drop in box office revenue in the U.S. and Canada, making it one of the weakest performances in years. ${ }^{9}$ However, navigating China's market is tricky at best and Hollywood must surmount several hurdles in order to ensure a foreign film is distributed in China. The first hurdle is the import quota China places on the importation of foreign films. The second is the State's censorship boards. By improving their understanding of both hurdles, more Hollywood studios will have better access to the Chinese market and gain practical solutions and adaptations to the problems within the current system.

This note critically examines various Chinese laws and practices that

7. See Clarence Tsui, 'Iron Man 3' China-Only Scenes Draw Mixed Response, HOLLYWOOD REP. (May 1, 2013, 1:25 PM), available at http://www.hollywoodreporter.com/news/iron-man-3-china-scenes-450184 (last visited Nov. 6, 2015).

8. See Erich Schwartzel \& Ben Fritz, Fewer American Go to the Movies, Wall St. J. (Mar. 25, 2014, 7:43 PM), available at http://online.wsj.com/articles/SB10001424052702303949704579461813982237426 (last visited Nov. 6, 2015).

9. Erich Schwartzel, Movie Chains Reel After a Summer of Few Hits, WALL ST. J. (Oct. 28, 2014, 7:58 PM), available at http://www.wsj.com/articles/movie-chains-reel-after-asummer-of-few-hits-1414540708 (last visited Nov. 6, 2015). 
impact Hollywood studios' access to the Chinese market. Further, this note examines the import and censorship system as it stands now. Part II illustrates the various hurdles and issues Hollywood studios must surmount when screening their films in China, including vague censorship regulations and strict import quotas. Part III uses various case studies to illustrate the vicissitudes of the Chinese censorship regime and predicts what sort of content will likely be deemed objectionable content by China's censorship boards. Part IV expands on the information discussed in the preceding two sections to outline the biggest problems faced by Hollywood studios in China today. Part V examines a recent World Trade Organization ("WTO") ruling against China's import restrictions on cultural products and asserts that pushing for China's compliance with the ruling would actually have a detrimental impact on Hollywood films in China. Finally, Part VI offers various solutions and practices that Hollywood studios should engage in to mitigate problems they currently face in the Chinese market.

\section{A. What Will Be Examined}

This note will only examine films produced by Hollywood studios. Here, Hollywood studios will be defined as the full-service movie studios geographically located in Hollywood, California. Examples of these studios include Warner Brothers., Paramount, Sony Pictures, Universal, Disney, The Weinstein Company, and $20^{\text {th }}$ Century Fox. ${ }^{10}$ However, this list may eventually expand to include China's Dalian Wanda Group Co., which is currently in talks with Lions Gate Entertainment Group, the studio behind The Hunger Games movie franchise, about buying Lions Gates shares. ${ }^{11}$ Dalian Wanda is also currently working towards building a Chinese version of Hollywood in Qingdao, a coastal city in eastern China, and even brought some major Hollywood stars in for the project's announcement. ${ }^{12}$ However, while this is certainly a project Hollywood studios should keep abreast of, the Chinese Hollywood in Qingdao is still under development and its full impact on Hollywood films remains to be seen. ${ }^{13}$

10. Sammy Said, The 10 Biggest Hollywood Studios, RicheST (Mar. 20, 2013), available at http://www.therichest.com/rich-list/the-biggest/the-10-biggest-hollywood-studios/ (last visited Nov. 6, 2015).

11. Ben Fritz \& Laurie Burkitt, Wanda Weighs Deal for Stake in Lions Gate, Wall ST. J. (Dec. 1, 2014, 2:05 PM), available at http://www.wsj.com/articles/dalian-wanda-groupheld-talks-with-lions-gate-1417449561 (last visited Nov. 6, 2015).

12. Id.

13. See Laurie Burkitt, Dalian Wanda Plans Fund to Lure Movie Business to China, 


\section{B. State of the Chinese Film Market Today}

Currently, China is the second largest market for film in the world and, arguably, is poised to take the number one spot from the U.S. ${ }^{14}$ In 2013, China was ranked as the number one global box office, having grossed \$3.6 billion, according to the Motion Picture Association of America, Inc. ${ }^{15}$ China also became the first international market to exceed $\$ 3$ billion in box office revenue. ${ }^{16}$ Once again, given the declining demand for film in movie theatres domestically, China's box office statistics are very appealing for Hollywood studios and represent a lucrative market and source of revenue.

However, while many Hollywood films have experienced success in Chinese theatres, this success is not necessarily guaranteed to continue. One of the things Hollywood studios needs to be aware of is not just their own popularity amongst Chinese viewers, but the growing domestic film industry as well. For example, domestic Chinese films dominated the Chinese box office in 2013, while Hollywood films only constituted only three of the ten highest grossing movies. ${ }^{17}$ Last year, domestic films accounted for $71 \%$ of the annual box office revenue. ${ }^{18}$ One of the possible reasons for the recent success in domestic Chinese films lies in the increasing number of movie theatres built across China, combined with the increasing quality, and content, of Chinese films. ${ }^{19}$

The most popular Chinese-made films are simple, personal tales of modern Chinese life, which lack much of the high-end special effects of many Hollywood films and resonate more with Chinese viewers. ${ }^{20}$ This shift in content preference is another element that Hollywood studios

WALL ST. J. (Oct. 7, 2014, 11:51 PM), available at www.wsj.com/articles/dalian-wandaplans-fund-to-lure-movie-business-to-china-1412740295 (last visited Nov. 6, 2015).

14. The Red Carpet, ECONOMIST (Dec. 21, 2013), available at www.economist.com/news/christmas-specials/21591741-red-carpet (last visited Nov. 6, 2015).

15. Theatrical Market Statistics 2013, Motion Picture Ass'N AM., InC. 5, available at http://www.mpaa.org/wp-content/uploads/2014/03/MPAA-Theatrical-Market-Statistics2013 032514-v2.pdf (last visited N, 2015).

16. $I d$.

${ }^{17}$ Katie Hunt, Hollywood Outshone as China Box Office Booms in 2013, CNN (Jan. 9, 2014, 1:23 AM), available at http://www.cnn.com/2014/01/09/world/asia/china-box-office-2013/ (last visited Nov. 6, 2015).

18. Id.

19. Id.

20. Michelle FlorCruz, China's Moviegoers Trading Up From Hollywood Explosions to Homegrown Humor, InT'L Bus. TIMES (May 9, 2014, 5:40 PM), available at http://www.ibtimes.com/chinas-moviegoers-trading-hollywood-explosions-homegrownhumor-1582482 (last visited Nov. 6, 2015). 
must consider as they pursue greater access to the Chinese market. The homegrown Chinese films do not only have the benefit of resonating with their viewers' lives, but also more accurately reflect their experiences in a way that Hollywood films do not. As the quality of Chinese films increase, they will provide more competition for Hollywood films and most of these films have the benefit of passing the state censors. ${ }^{21}$

Going to the movies has become a large part of China's culture. It has particularly become part of the courtship ritual and a common activity for couples out on dates. ${ }^{22}$ It has also become more common given that an increasing number of Chinese citizens are experiencing an increase in spending power and disposable income. ${ }^{23}$ As China's economy continues to grow and more luxury items, such as tickets to large movie theatres, become more readily available, the demand for films will more than likely increase, as will the viewers' standards and expectations for the quality and content of these films. Hollywood studios need to keep these factors in mind as they continue to direct their efforts towards the Chinese market.

China has shown its potential as a great source of revenue, but the rules that apply in the U.S. do not apply in China. For example, Hollywood studios do not face content censorship from the U.S. government-rather, it applies its own voluntary film rating system to indicate each film's content and appropriateness for younger viewersand, in fact, the U.S. film industry has a history of fighting against government censorship. ${ }^{24}$ Moreover, Hollywood studios can expect a certain level of protection for their films under U.S. copyright and intellectual property laws, which are designed to encourage creative growth and development within the industry rather than to serve as an instrument of control. ${ }^{25}$ This level of personal control over content and the protections provided by U.S. law are not the same as what may be available in China, and these differences need to be acknowledged and understood by the Hollywood studios that wish to access the Chinese market.

21. See infra Part II.

22. The Red Carpet, supra note 14.

23. $I d$.

24. See Preserving Free Speech, Motion Picture Ass'N Am., available at http://www.mpaa.org/preserving-free-speech/ (last visited Nov. 6, 2015).

25. See Why Copyright Matters, Motion PiCTURE Ass'N AM., available at http://www.mpaa.org/why-copyright-matters/ (last visited Nov. 6, 2015). 


\section{BACKGROUND \& THE SYSTEM AS IT STANDS NOW}

This section will examine both China's censorship regime and the quotas it imposes on foreign films. Censorship will be addressed first, as it has a larger impact on Hollywood films because the censorship regime seeks to change the actual content of a film, whereas the import quotas merely limit the number of films that can be brought into China per year.

\section{A. Who Censors?}

The Chinese government has a history of sensitivity to the influence and impact that cultural products can have on the country's people, and film certainly falls into this category. Movies are considered a "cultural market," and in regards to foreign films, have been viewed as a product of "the political, economic, military, and cultural invasions of the West." 26 While the view towards foreign films is not quite so extreme in today's China, it is still an area which the government feels needs to be regulated, censored, and subjected to strict review. ${ }^{27}$ However, the mechanisms through which this regulation, censorship, and review operate tend to be rather complex and opaque.

When China acceded to the WTO in December of 2001, it agreed that, within three years of this accession, all enterprises in China, including foreign individuals and enterprises, even those not invested or registered in China, would have the right to import and export all goods not reserved for trading by designated State Owned Entities ("SOE") throughout its customs territory. ${ }^{28}$ While cultural or information products, a category which includes film, were not mentioned as one of the products reserved to SOEs, the importation and distribution of foreign films is nonetheless still barred to those entities not given state authorization. ${ }^{29}$ The continued refusal to grant non-SOEs the right to import and distribute foreign films has recently caused tensions between the U.S. and China, where the U.S. brought a case against China to the WTO. $^{30}$

Currently, the China Film Corporation is the country's largest film

26. Shujen Wang, Framing Piracy: Globalization and Film Distribution in GREATER CHINA 61 (2003).

27. See id.

28. Julia Ya Qin, Pushing the Limits of Global Governance: Trading Rights, Censorship, and WTO Jurisprudence-A Commentary on the China-Publications Case, 10 CHINESE J. INT'L L. 1, 5 (2011).

29. See id. at 5-6.

30. See infra Part V. 
enterprise. ${ }^{31}$ It is responsible for regulating film distribution throughout the country, including import and export operations. ${ }^{32}$ Two bodies operate beneath it: the China Film Import and Export Corporation, which handles the import and export of films, and the China Film Distribution and Exhibition Bureau, which, along with its own various subsidiaries, own the majority of movie theatres in China. ${ }^{33}$ The China Film Distribution and Exhibition Bureau and its subsidiaries also have the power to dictate the contractual terms of film distribution and exhibition, as well as the play dates, admission prices, and other aspects of film exhibition. $^{34}$ In March of 2003, another distributor was created, the Huaxia Film Distribution group which has the power to distribute foreign films, but unfortunately cannot import these films. ${ }^{35}$ Below these are the provincial distributors and exhibitors, which are a part of the China Film Distribution and Exhibition Association, and these bodies deal directly with the foreign studios. ${ }^{36}$ These bodies deal directly with film importation and distribution, but there is a level of regulatory bodies above them that is important to note.

Two major government organizations are above these SOEs, which govern the operations of media industries in China: the State Administration of Radio, Film, and Television ("SARFT") and the Ministry of Culture. ${ }^{37}$ SARFT is responsible for regulating film for theatrical release and distribution, radio, and television, while the Ministry of Culture is responsible for monitoring the home video import and distribution business. ${ }^{38}$ Its power to censor lies in its licensing power, both in granting licenses and revoking them, for foreign film distributors in China. ${ }^{39}$ Subsequently, these are overseen by the Communist Party's Central Propaganda Department ("CPD"), the highest body in China responsible for media regulations and access to information. ${ }^{40}$ The CDP

31. WANG, supra note 26 , at 61-62.

32. Id. at 62 .

33. Id.

34. Id.

35. Firedeep \& Robert Cain, How China's Movie Distribution Works, Part 1, CHINAFILMBIZ (Nov. 7, 2012), available at http://chinafilmbiz.com/2012/11/07/how-chinasmovie-distribution-system-works-part-1/ (last visited Nov. 6, 2015).

36. Id.; WANG, supra note 26 , at 62 .

37. WANG, supra note 26 , at 62 ; see Firedeep \& Cain, supra note 35.

38. WANG, supra note 26, at 62.

39. Agencies Responsible for Censorship in China, Cong.-Executive Commission on CHINA, available at http://www.cecc.gov/agencies-responsible-for-censorship-in-china\#sarft (last visited Nov. 6, 2015).

40. Michael Ting, The Role of the WTO in Limiting China's Censorship Policies, 48 
is the Communist Party's counterpart to SARFT and is responsible for monitoring content of publications and media to ensure that nothing inconsistent with the Party's political dogma gets disseminated. ${ }^{41}$ This set up allows the government to keep tight control over its film imports, as well as ensuring that its censorship process is nontransparent to provide systems "with the maximum level of flexibility and efficacy desired." 42

The State Secrets Bureau is yet another agency that controls much of the Chinese censorship regime, which uses China's state secrets laws to designate "practically all information relating to China's government, economy, diplomacy, technology, and military" as being a potential state secret. ${ }^{43}$ The State Secrets Bureau also ensures that it is the Chinese citizens, and not the government, that are responsible for maintaining these state secrets. ${ }^{44}$ In other words, each citizen is responsible, by law, for maintaining any information they have that could be construed as a state secret, especially if they are engaged in any sort of business or communication with foreigners. ${ }^{45}$ Arguably, this agency and the state secrets laws have a chilling effect on freedom of speech in China ${ }^{46}$ and contribute to the opaqueness of China's censorship regime.

However, as Hollywood seeks to get more of its films into the Chinese market, it is not just the Chinese government that censors. There have been several indications that Hollywood engages in self-censorship when it comes to films it wants to pitch to China. ${ }^{47}$ For example, the 1990s saw several films about Tibet produced, films such as Seven Years in Tibet and Disney's Kundun, a biographical movie about the 14th Dalai Lama's youth, both of which raised Beijing's hackles. ${ }^{48}$ The Beijing government's displeasure was so great that it is reported that Brad Pitt, one of the Seven Years in Tibet's stars, is banned from entering China due

H.K. L. J. 285, 288 (2011).

41. Agencies Responsible for Censorship in China, supra note 39.

42. Ya Qin, supra note 28, at 2.

43. Agencies Responsible for Censorship in China, supra note 39.

44. Id.

45. See International Agreements and Domestic Legislation Affecting Freedom of Expression, CONG.-EXECUTIVE COMMISSION ON CHINA, available at http://www.cecc.gov/international-agreements-and-domestic-legislation-affecting-freedomof-expression\#secretsonnetworkslaw (last visited Nov. 6, 2015).

46. See id.

47. Erica Ho, Can Hollywood Afford to Make Films China Doesn't Like?, Time (May 25, 2011), available at $\mathrm{http} / /$ content.time.com/time/world/article/0,8599,2072194,00.html (last visited Sept. 7, 2015).

48. Id. 
to his role in the film, and the government also threatened to cut off all future business with Disney. ${ }^{49}$ Beijing's response to films it considers either critical of its regime or sympathetic to a cause China opposes, such as Tibetan independence or sympathy for the Dalai Lama, may now very well mean that such films will no longer be produced by Hollywood studios. ${ }^{50}$ While self-censorship is a response to China's own censorship regime, it remains a factor needing serious attention, as the Chinese market is likely to continue requiring such practices.

\section{B. Laws and Regulations Governing and Impacting Chinese Censorship}

While there is no single, omnibus censorship law in China, there are several laws and regulations that play a large part in the Chinese censorship regime. The Chinese censorship regime is better viewed as a patchwork of various regulations and measures covering all forms of media, including newspapers and periodicals, the Internet and satellite television. $^{51}$ One of the most directly pertinent regulations to film censorship is a circular released by SARFT in 2008, reiterating its criteria for censoring radio, film and television. ${ }^{52}$ The circular was released "to give priority to protecting the healthy development of minors and social welfare; further encourage creativity, tighten control, and purify screen entertainment; provide healthy and rich nourishment for the mind; and build a more harmonious and 'green' film environment." 53 The circular succinctly lists the provisions initially laid out in the Regulations on the Administration of Films and Provisions on the Filing of Film Scripts (Abstracts) and Administration of Films and calls on all departments and units to strictly enforce these regulations. ${ }^{54}$ It divides content into two broad categories: prohibited content and content that must be cut or altered. ${ }^{55}$ According to the circular, films may not contain content which:

(1) Violates the basic principles of the Constitution; (2) Threatens the unity, sovereignty and territorial integrity of the state; (3) Divulges state secrets, threatens national security, harms the reputation and interests of the state; (4) Instigates national hatred and discrimination,

49. Id.

50. See id.

51. See Cong.-Executive Commission on China, supra note 45.

52. SARFT Reiterates Film Censor Criteria, H.K. Trade Dev. Council (Apr. 1, 2008), available at http://info.hktdc.com/alert/cba-e0804c-2.htm (last visited Nov. 6, 2015).

53. Id.

54. Id.

55. Id. 
undermines the harmony among ethnic groups, or harms ethnic customs and practices; (5) Violates state policies on religion, and propagates cult religion or superstition; (6) Disrupts social order or social stability; (7) Propagates obscenity, gambling, violence, or abets criminal activities; (8) Insults or defames others, or infringes upon others' legitimate rights and interests; (9) Corrupts social morality, or defames the superiority of national culture; (10) Other contents prohibited by state laws and regulations. $^{56}$

The circular also states that films containing certain content must be cut or altered, including content that is:

(1) Distorting Chinese civilization and history; seriously departing from historical truth; distorting the history of other countries, disrespecting other civilizations and customs; disparaging the image of revolutionary leaders, heroes and important historical figures; tampering with Chinese or foreign classics and distorting the image of the important figures portrayed therein; (2) Disparaging the image of the people's army, armed police, public security organ or judiciary; (3) Showing obscene and vulgar content, exposing scenes of promiscuity, rape, prostitution, sexual acts, perversion, homosexuality, masturbation and private body parts including the male or female genitalia; containing dirty or vulgar dialogues, songs, background music and sound effects; (4) Showing contents of murder, violence, terror, ghosts and the supernatural; distorting value judgment between truth and lies, good and evil, beauty and ugliness, righteous and unrighteous; showing deliberate expressions of remorselessness in committing crimes; showing specific details of criminal behaviors; exposing special investigation methods; showing content which evokes excitement from murder, bloodiness, violence, drug abuse and gambling; showing scenes of mistreating prisoners, torturing criminals or suspects; containing excessive horror scenes, dialogues, background music and sound effects; (5) Propagating passive or negative outlook on life, world view and value system; deliberately exaggerating the ignorance of ethnic groups or the dark side of society; (6) Advertising religious extremism, stirring up ambivalence and conflicts between different religions or sects, and between believers and non-believers, causing disharmony in the community; (7) Advocating harm to the ecological environment, animal cruelty, killing or consuming nationally protected animals; (8) Showing excessive drinking, smoking and other bad habits; (9) opposing the spirit of the law. ${ }^{57}$

This ninth category is a catch-all category for any content not

57. SARFT Reiterates Film Censor Criteria, supra note 52. 
explicitly captured by the preceding categories, to ensure that SARFT maintains flexibility in determining acceptability of content.

The Law of the People's Republic of China on Guarding State Secrets ("State Secrets Law") also has a great impact on China's censorship regime, albeit not an obvious one. Article 1 of the State Secrets Law sets out the purpose of the law, providing "[T]his Law is formulated for the purpose of guarding State secrets, safeguarding State security and national interests and ensuring the smooth progress of reform, of opening to the outside world, and of socialist construction." 58 The law then defines state secrets as "matters that have a vital bearing on State security and national interests and, as specified by legal procedure, are entrusted to a limited number of people for a given period of time." 59 While the law itself does not directly cite foreign films or the organizations that handle them, the breadth and potential implications of some of the law's provisions could certainly have an impact on the Chinese entities that import and distribute foreign films. The law does have a provision stating that "[i]n the publication and distribution of newspapers, journals, books, maps, material with illustrations and captions, and audio and video products and in the production and broadcast of radio and television programmes and films, the relevant security regulations will be complied with and no State secrets shall be divulged."60

For example, the State Secrets Law applies to "all State organs, armed forces, political parties, public organizations, enterprises, institutions and citizens," imposing the obligation to guard state secrets on all of these groups. ${ }^{61}$ Given the broad scope this obligation applies to, it is very possible for the SOEs and other Chinese organizations that import, distribute, and exhibit foreign films to be subject to this obligation as well. Another relevant provision of the law is the article which defines, in further detail, what state secrets shall encompass, including secrets concerning major policy decisions on state affairs and "other matters that are classified as state secrets by the state-guarding department." 62 This provision could, arguably, extend to any censorship decision issued by

58. Zhonghua renmin gongheguo baoshou guoiia mimi fa (中华人民共和国保守国家 秘密法) [Law on Guarding State Secrets] (promulgated by the Nat'l People's Cong. Standing Comm., Sept. 5, 1988, effective May 1, 1989), art. 1 [hereinafter Law on Guarding State Secrets].

59. Id. art. 2 .

60. Id. art. 20.

61. Id. art. 3 .

62. Id. art. 8 . 
either SARFT or the CPD, so long as it could be argued that such a decision constitutes a major policy decision on state affairs. Further, depending on how serious the secret divulged was, the type of punishment attached could either fall into the criminal realm or into the administrative realm. ${ }^{63}$

Administrative punishments would include revoking permits or licenses, fines, and freezing of property. ${ }^{64}$ These punishments are handed down by the administrative agency that promulgated the administrative act. ${ }^{65}$ Here, this would most likely be the State Secrecy Bureau and would more than likely constitute a fine or the revocation of the distributor's license. Criminal punishments, on the other hand, are much more serious and carry much greater consequences for those being prosecuted under this area of law. In China, the criminal law states "any act which endangers state sovereignty and territorial integrity and security, splits the state, jeopardises the political powers of the people's democratic dictatorship and socialist system, undermines social and economic orders ... or any other act which endangers society" is liable to be punished under China's criminal law. ${ }^{66}$ The punishments that come from China's criminal system include control and supervision of the convicted, with sentences lasting anywhere from two months to two years; criminal detention, which ranges from one month to six months; fixed term imprisonment, lasting anywhere between six months to fifteen years; life imprisonment; or the death penalty. ${ }^{67}$ The Chinese criminal law also features three other supplementary punishments: fines with no specified limit, deprivation of political rights, and confiscation of property. ${ }^{68}$ Given the potential consequences of revealing state secrets, it is not surprising that censorship decisions handed down by SARFT to the SOEs managing foreign film imports are not made readily available to Hollywood studios.

China's State Secrets Law also works in tandem with the Measures for Implementing the Law on the Protection of State Secrets ("Measures"), which is a set of measures providing for the retroactive classification of information not already a state secret as a state secret if it proves harmful to state security or interest. ${ }^{69}$ Article 4 of the Measures

63. See Law on Guarding State Secrets, supra note 58, art. 31.

64. Jianfu Chen, Chinese Law: Context And Transformation 224-25 (2008).

65. Id. at 223.

66. Id. at 280 .

67. Id. at 282 .

68. Id.

69. State Secrets: China's Legal Labyrinth, Hum. RTs. CHINA 94 (2007), available at 
is the source of the law's retroactive power and it lists eight different results that may possibly place information within the scope of state secrets. ${ }^{70}$ Article 4(3), provides - "[h]arming the political or economic interests of the state in its dealings with foreign countries"-may be the scenario most pertinent to foreign films in China, depending on how the country views its censorship criteria at the time. ${ }^{71}$ The strictures of the State Secrets Law were tightened even further when the law was revised in $2010 .{ }^{72}$ The new revisions include provisions restricting the export of electronic data before it can be reviewed and cleared of sensitive information. ${ }^{73}$ While the impact this may have on film imports is not readily apparent, many Western companies, including Hollywood studios, have regular dealings with China's SOEs, and therefore receive regular information and communications from these SOEs. ${ }^{74}$ Any communication from an SOE regarding the censor's decision on a film seeking release in China could possibly fall under the State Secrets Law, particularly given the law's retroactive power. ${ }^{75}$

\section{Import Quotas}

Despite China joining the WTO in December of $2001,{ }^{76}$ the country still maintained a strict import quota over foreign films, permitting only twenty foreign films to be released there per year. ${ }^{77}$ However, following Chinese President Xi Jinping's visit to the U.S. in 2012, an agreement was struck to allow fourteen more films into the country per year, provided that they are in either IMAX or 3D formats. ${ }^{78}$ This quota was still maintained despite a WTO ruling against China in a 2009 case brought by the U.S. over the claim that China's limit of books, songs, and

http://www.hrichina.org/sites/default/files/PDFs/State-Secrets-Report/HRIC_StateSecretsReport.pdf (last visited Nov. 6, 2015).

70. See id. at 96 .

71. Id.

72. Michael Vella \& Jerry Ling, Traps for the Unwary in Disputes Involving China, JONES DAY (Aug. 2012), available at http://www.jonesday.com/traps_for_unwary/ (last visited Nov. 6, 2015).

73. Id.

74. Id.

75. See id.

76. Ya Qin, supra note 28, at 5.

77. Mary Hennock, Boost for Hollywood Studios as China Agrees to Ease Quota on US Films, GUARDIAN (Feb. 20, 2012, 8:17 AM), available at http://www.theguardian.com/world/2012/feb/20/china-eases-import-quota-hollywood-films (last visited Oct. 22, 2015).

78. Id. 
movies imports violated WTO rules. ${ }^{79}$

While the ruling itself did not have a direct impact on the quota that caps the number of foreign films allowed to enter China each year, it was meant to permit more than just select SOEs to import foreign films into China, including foreign companies to import and distribute films. ${ }^{80}$ For the U.S., the WTO ruling meant that American movie studios, among other media distributors, would have the ability to sell their products more directly to Chinese consumers. ${ }^{81}$ However, China has not yet complied with this ruling in full. ${ }^{82}$ This is not necessarily an insufferable obstacle for Hollywood studios, although the implications of full compliance may have a detrimental impact on Hollywood studios' ability to maximize their access to the Chinese market. ${ }^{83}$

\section{Revenue-Sharing}

One of the revenue gathering methods under which a studio may calculate its Chinese earnings is the revenue-sharing scheme. Initially, under this system, the film's distributor and exhibitor will negotiate what percentage of the box office receipts each will receive, as well as ensure that the Hollywood studio receives roughly $15 \%$ of the box office revenue. ${ }^{84}$ This system, of course, means that the majority of the revenue generated by a foreign film remains in China with the Chinese distributor and exhibitor. In 2012, however, a deal was struck between China and the U.S. that boosted the revenue percentage to $25 \% .{ }^{85}$ This new revenue percentage still means that the majority of profits remain in China, but it does represent a substantial increase from the prior system, where studios were paid on a sliding scale ranging from $13 \%$ to $17 \%$ of the generated box office revenue. ${ }^{86}$ While $25 \%$ may not seem like a large percentage, when one considers the amount of money generated at the Chinese box office-2011's Transformers: Dark of the Moon alone made U.S. \$173

\footnotetext{
13 ,

79. Keith Bradsher, W.T.O. Rules Against China's Limits on Imports, N.Y. TIMES (Aug. http://www.nytimes.com/2009/08/13/business/global/13trade.html?pagewanted=all\&_r=0 (last visited Nov. 6, 2015).
}

80. See id.

81. Id.

82. Ya Qin, supra note 28, at 2.

83. See discussion infra Part V.

84. WANG, supra note 26, at 63.

85. Patrick Frater, China's Quota Change Heralds Reform, Competition, FILM Bus. AsIA (Feb. 23, 2012, 4:16 PM), available at http://www.filmbiz.asia/news/chinas-quotachange-heralds-reform-competition (last visited Nov. 6, 2015).

86. $I d$. 
million at the box office in China-a whole quarter of the profits represents a large cash flow for U.S. studios. ${ }^{87}$ The other system used to import foreign films into Chinese theatres is the flat fee system, which operates under slightly different rules than the revenue-sharing system. ${ }^{88}$

\section{CASE STUDIES}

To better examine the issues arising in passing the censors and distribution, this note examines three categories of films: those rejected outright for distribution; those accepted after certain changes have been made to the film; and those accepted and then pulled from theatres after distribution. It is not entirely clear why certain movies fall into one of the three categories, but the shifting censorship standards likely provide a partial answer.

\section{A. Outright Rejection}

For example, the film Noah, a modern film on the Biblical story of God's great flood starring Russell Crowe, was outright rejected for distribution. ${ }^{89}$ While the film's producers tried to satisfy the censors by claiming the focus of the movie is environmental issues and not religious ones, the censors did not accept this rationale and denied permission for distribution..$^{90}$ One explanation for the film's rejection was that certain domestic films that were slated for release around this time and that the government wanted to promote these films over those produced by other countries' industries. ${ }^{91}$ However, the religious tone or at least background to the film was likely a large reason behind the film's rejection. While the Chinese Constitution purports to guarantee freedom of religion, this freedom is curtailed by the need to protect the health and safety of the State and its people. ${ }^{92}$ The film was intended to screen mid-

87. Id.

88. This particular system is not subject to the same strict quotas as the films imported under the revenue-sharing system. Rather, after the 2012 deal between China and the U.S., approximately 40 films are now imported into China each year under, as the name implies, a fixed flat fee. See id.

89. Cheryl K. Chumley, 'Noah' Way! Movie Blocked in China, Banned by Muslim Nations, WASH. TIMES (May 9, 2014), available at http://www.washingtontimes.com/news/2014/may/9/noah-blocked-china-banned-muslimnations/ (last visited Nov. 6, 2015).

90. Id.

91. Id.

92. See XiAnFA art. 36 (1982) (China) (“Citizens of the People's Republic enjoy freedom of religious belief. No state organ, public organization or individual may compel citizens to believe in, or not to believe in, any religion; nor may they discriminate against citizens who 
May and to be imported on a flat-fee basis, meaning it was not constrained by the thirty-four foreign film quota of the revenue-sharing scheme, but did not gain the censors' approval. ${ }^{93}$

Despicable $\mathrm{Me} 2$ was also outright rejected for distribution in China. ${ }^{94}$ Unlike with Noah, there was a bit of controversy over whether the film was actually denied release in China or whether the film had been presented for release at all. ${ }^{95}$ However, one allegation as to why the film was not released in China was that the minion characters "bore an unfortunate likeness to erstwhile Chinese leader Jiang Zemin."96 Others claim that it was determined that the film simply would not perform well in China, and therefore was not given one of the limited revenue-sharing slots. ${ }^{97}$ Which is actually true remains unclear, though it is interesting to note that the first Despicable Me film was also denied release in China. ${ }^{98}$ Nonetheless, Despicable Me 2 ultimately did not screen in China, for reasons that are not entirely clear, exemplifying just how arbitrary and unclear the process is.

\section{B. Accepted After Adjustments/Self-Censorship}

Further, World War $Z$ was only accepted for distribution after certain changes and adjustments were made to the film. ${ }^{99}$ In this instance, the studio decided to make certain pre-emptive changes to the film, in anticipation that certain elements would be considered objectionable by Chinese censors. ${ }^{100}$ Surprisingly, it was not the film's violence that worried the studio, but one rather small plot point instead. ${ }^{101}$ Initially,

believe in, or do not believe in, any religion. The state protects normal religious activities. No one may make use of religion to engage in activities that disrupt public order, impair the health of citizens or interfere with the educational system of the state. Religious bodies are not subject to any foreign domination.").

93. Katie Nelson, Hollywood Biblical Epic 'Noah' Denied Release Slot in China, SHANGHAIIST (May 9, 2014, 9:00 PM), available at http://shanghaiist.com/2014/05/09/noahdenied-release-slot-china.php (last visited Nov. 6, 2015).

94. Ben Child, China Denies Despicable Me 2 Ban, Guardian (Aug. 6, 2013, 06:27 $\mathrm{AM}$ ), available at http://www.theguardian.com/film/2013/aug/06/china-denies-despicableme-2-ban (last visited Nov. 6, 2015).

95. Id.

96. Id.

97. $I d$.

98. Id.

99. Lucas Shaw, Fearing Chinese Censors, Paramount Changes 'World War Z', WRAP (March 31, 2013, 6:39 PM), available at http://www.thewrap.com/movies/article/fearingchinese-censors-paramount-changes-world-war-z-exclusive-83316/ (last visited Nov. 6, 2015).

100. Id.

101. Id. 
when the characters were debating the origins of the zombie virus, they cited China as the source of the outbreak. ${ }^{102}$ The studio, well aware of China's mercurial censorship regime and its sensitivity to any negative commentary on the country, advised the studio to drop the reference to China and instead left the origins of the virus unknown. ${ }^{103}$ This is a prime example of the self-censorship Hollywood studios are willing to resort to in order to better their chances of getting a film past the Chinese censors. The change made was small, and most likely unnoticeable to American audiences, but is a significant example of the power and influence of China's censorship regime.

Skyfall, one of the latest James Bond films, is another film subjected to strategic cuts. In this instance, as opposed to the small change made to World War Z, an entire scene was omitted, along with several other alterations to dialogue. ${ }^{104}$ The scene cut from the original version was set in Shanghai and featured a French hit man shooting a Chinese security guard in the elevator lobby of a skyscraper. ${ }^{105}$ Another scene taking place in Macau was edited as well. In this scene, James Bond is questioning a woman about her tattoo, asking her if it came about as a result of being forced into a prostitution ring at an early age. ${ }^{106}$ In English, the lines remained untouched but the Chinese subtitles changed the conversation from prostitution to the tattoo resulting from being coerced into a criminal mob instead. ${ }^{107}$ Other moments in the film were simply removed from the film. For example, the villain's backstory about being handed over to Chinese authorities while working for MI6 in Hong Kong and being subjected to extreme torture at the hands of his captors was cut from the film. ${ }^{108}$

\section{Accepted and then Later Pulled from Theatres}

Another common scenario is to see films get accepted for distribution, pass the censors, start being screened, and then get pulled from theatres soon after its release. A good example of this scenario is the Quentin Tarantino film, Django Unchained. The film was set to be

102. Id.

103. Id.

104. Clarence Tsui, Chinese Censors Clamp Down on 'Skyfall', Hollywood ReP. (Jan. 6, 2013, 10:06 PM), available at http://www.hollywoodreporter.com/news/chinese-censorsclamp-down-skyfall-413140 (last visited Nov. 6, 2015).

105. Id.

106. Id.

107. Id.

108. Id. 
released in China early 2013, after a few small demands to change things such as the color and amplitude of blood, which were considered to be too bright and too prominent, featured in the film. ${ }^{109}$ However, on the morning of its release, just minutes into the first screening, the film was stopped and then pulled from theatres. ${ }^{110}$ It was most likely the violence or the nudity featured in the original film. ${ }^{111}$ However, the film had already undergone some sanitization prior to its Chinese release and the film also already passed through the censors' hands, making it even more unclear as to why the film was suddenly pulled. ${ }^{12}$ The film was eventually reapproved and rereleased three weeks later, after several scenes containing nudity and violent murder were removed. ${ }^{113}$ The film also experienced reduced screening after its release was scaled back. ${ }^{114}$

However, Django Unchained was not the only Hollywood film subjected to this yo-yo like treatment. In fact, in some cases a film can be pulled just before it was set to be released. An example is the film Outcast, starring Nicolas Cage. ${ }^{115}$ The film is about two crusaders in China during the twelfth century and it was pulled from theatres soon after its initial release. ${ }^{116}$ The film was set for release on September 26, 2014, but was pulled from release the evening of September $25 .{ }^{117}$ The reasons for the last minute change of heart are unclear and speculation ranges from financial difficulties on the Chinese film group's end to the

109. Richard Brody, "When Night Falls" and "Django Unchained": Movie Censorship in China, NEW YORKER (May 23, 2013), available at http://www.newyorker.com/culture/richard-brody/when-night-falls-and-django-unchainedmovie-censorship-in-china (last visited Nov. 6, 2015).

110. Jonathan DeHart, Django Unchained (Again) With Cuts in China, DIPLOMAT (April 30, 2013), available at http://thediplomat.com/2013/04/django-unchained-again-withcuts-in-china/ (last visited Nov. 6, 2015).

111. Id.

112. Id.

113. See also id.; Clarence Tsui, 'Django Unchained' Reopens in China with Nudity and Screenings Reduced, HOLLYwOOD REP. (May 13, 2013, 2:51 AM), available at http://www.hollywoodreporter.com/news/django-unchained-reopens-china-nudity-521650 (last visited Nov. 6, 2015).

114. Tsui, supra note 113.

115. Richard Verrier \& Julie Makinen, Nicolas Cage Movie, 'Outcast,' Pulled from Theaters in China, L.A. TIMES (Sept. 26, 2014, 1:02 PM), available at $\mathrm{http} / /$ www.latimes.com/entertainment/envelope/cotown/la-et-ct-china-film-dispute20140926-story.html (last visited Nov. 6, 2015).

116. Id.

117. Patrick Frater, Nicolas Cage's 'Outcast' Gets China Relaunch, eOne as U.S. Distributor, VARIETY (Nov. 4, 2014, 7:55 AM), available at http://variety.com/2014/film/news/nicolas-cages-outcast-gets-china-relaunch-eone-as-u-sdistributor-exclusive-1201347000/ (last visited Nov. 6, 2015). 
censors reconsidering their approval given the film's alleged high body count and graphic battle images. ${ }^{118}$ As of now, the film has still not been released in China, but is slated to be in Chinese theatres in January 2015..$^{119}$

\section{Accepted With No Issues}

One notable example of a film that was smoothly accepted, at least from the censorship regime's perspective, was the fourth Transformers movie, Transformers: Age of Extinction. The film took the top spot as China's number one grossing film only ten days after its release in theatres, raking in a total of U.S. \$222.7 million. ${ }^{120}$ In fact, the film performed better in China than it did in its own domestic market. ${ }^{121}$ It premiered in Hong Kong and closed at the Shanghai International Film Festival, registering 338,793 screenings across China. ${ }^{122}$ Much of the film's success can be attributed to its innate appeal to Chinese audiences. For example, the film used many highly visible sites in Beijing and Hong Kong throughout the film, as well as a scenic spot near the city of Chongqing. ${ }^{123}$ A couple of famous actors and actresses have roles in the film as well, including actress Li Bingbing and actor Han Geng, both very famous Chinese actors. ${ }^{124}$ There was even a slew of product placement throughout the film for "everything from Chinese milk and PCs to Red Bull and authoritarian styles of government."125

However, while the film did not experience any serious troubles from the Chinese censorship regime, it did not come through its Chinese experience unscathed. The film was threatened by two different lawsuits, one prior to the film's screening and one after. ${ }^{126}$ The first threatened

118. Id.

119. Id.

120. Clifford Coonan, China Box Office: 'Transformers: Age of Extinction' is No. 1 Film of All Time, HOLLYwOOD REP. (July 7, 2014, 8:54 PM), available at $\mathrm{http} / /$ www.hollywoodreporter.com/news/transformers-age-extinction-becomes-chinas717083 (last visited Nov. 6, 2015).

121. See id.

122. Id.

123. Id.

124. Id.

125. Coonan, supra note 120.

126. See Brent Lang, 'Transformers: Age of Extinction' China Sponsor Demands $\$ 1.8$ Mil Investment Back, VARIETY (Jun. 24, 2014, 8:08 AM), available at http://variety.com/2014/film/news/transformers-age-of-extinction-china-sponsor-demands1-8-mil-investment-back-1201244725/ (last visited Nov. 6, 2015); see also Ji Jin \& Cao Yin, Transformers' Producers Hit With Breach of Contract Suit, CHINA DAILY USA (Jul. 25, 2014, 7:20 AM), available at http://usa.chinadaily.com.cn/epaper/2014- 
lawsuit came from one of the film's Chinese sponsors, Beijing Pangu Investment Co., a real estate development company, and was against two of the film's other sponsors, though not against the studio itself. ${ }^{127}$ While the suit may not have been a direct threat to the studio itself, it did threaten to delay the film's theatrical release. ${ }^{128}$ In contrast, the second lawsuit, post-release, was aimed at the studio and involved a Chinese tourism company, the Chongqing Wulong Karst Tourism Group. ${ }^{129}$ The Wulong Karst Tourism Group claimed that the studio breached a contract by failing to show the logo of a Chongqing scenic spot in the film. ${ }^{130}$ The tourism company filed suit in Chongqing No. 3 Intermediate People's Court, which has accepted the case. ${ }^{131}$ However, while these issues complicated the film's release, in terms of China's censorship regime, Transformers: Age of Extinction experienced a relatively smooth release journey in China.

\section{PROBLEMS WITH THE CURRENT SYSTEM}

\section{A. Factors that will Predictably Lead to Rejection Based on Past Experience}

Despite SARFT's circular, which concisely reiterates the administration's censorship criteria, there is still a fair amount of uncertainty over what content will meet with rejection the censors and what content will pass. ${ }^{132}$ However, these somewhat vague guidelines do still allow certain insights into what sort of content will most likely be rejected by the state censors. For example, anything that blatantly disparages Chinese culture would likely fall under the category of defaming the superiority of China's national culture. ${ }^{133}$ It is also more than likely that any film overtly critical of the Chinese Communist Party or the Chinese government would be struck down by the censors.

It is difficult to determine what constitutes overt criticism. What

07/25/content_17924587.htm (last visited Nov. 6, 2015).

127. Lang, supra note 126.

128. Id.

129. Id.

130. Id.

131. Id.; Brenda Goh, Chinese Tourism Company Sues Paramount Over Transformers

4 Scenes, REUTERS (Jul. 25, 2014, 4:07 AM), available at http://www.reuters.com/article/2014/07/25/flim-china-transformers-

idUSL6N0Q013420140725 (last visited Dec. 7, 2014). No other information on the case appears to be available as of yet.

132. See SARFT Reiterates Film Censor Criteria, supra note 52.

133. Id. 
constitutes criticism of the Chinese Communist Party or the Chinese government is not readily apparent from SARFT's criteria. Certain films have made it past the censors and were screened in China, such as The Hunger Games. ${ }^{134}$ At first glance, it seems a bit surprising that The Hunger Games, a film about a totalitarian government which forces its people to send their children into an arena to fight to the death every year, did not get condemned by the censors. It would be easy to envision the possible parallels between the Capitol government in The Hunger Games and the political elite situated in Beijing. ${ }^{135}$ Not only did the first film in the series make it onto Chinese screens, but the sequel did as well. ${ }^{136}$ Perhaps it had something to do with the idea that the film was set in an imaginary society and was considered far enough removed from modern China to deem it safe. Yet, unexpectedly, or perhaps not unexpectedly, the third film in the franchise is facing issues with its release in China. ${ }^{137}$ The film's release date was cancelled indefinitely, likely because of the movie's plot to overthrow the government. ${ }^{138}$ When the subject matter is remote enough from Chinese life, it passes the censors, but once the subject matter begins to touch on something the present Chinese government arguably fears, the censors will refuse permission.

Another theme that is likely to face rejection is religious themes, as seen with the censors' rejection of Noah. ${ }^{139}$ However, a blanket claim that no films with religious themes will pass the censors would not necessarily be accurate. Kung Fu films, such as The Shaolin Temple starring Jet $\mathrm{Li}$, are widely popular in China and many are produced domestically. ${ }^{140}$ More accurately, films with predominately Western

134. See Etan Vlessing, 'Hunger Games: Catching Fire' Gets Nov. 21 China Release, HOLLYWOOD REP. (Oct. 22, 2013, 6:41 AM), available at http://www.hollywoodreporter.com/news/hunger-games-catching-fire-gets-649996 (last visited Nov. 7, 2015).

135. For example, viewers could possibly draw parallels between China's alleged suppression of freedom and expression and assembly and the fictional Capitol's authoritarian regime.

136. See Vlessing, supra note 134.

137. See Michelle FlorCruz, 'The Hunger Games: Mockingjay - Part 1' China Premiere Canceled: Rebellion Plot Could Cost Movie Millions in China Market, INT'L Bus. TimeS (Nov. 18, 2014, 12:27 PM), available at http://www.ibtimes.com/hunger-games-mockingjaypart-1-china-premiere-canceled-rebellion-plot-could-cost-1725591 (last visited Nov. 7, 2015).

138. Id.

139. See Chumley, supra note 89.

140. See IMDB Top 250 Martial Arts Movies of All Time, IMDB, available at http://www.listchallenges.com/imdb-top-250-martial-arts-movies-of-all-time (last visited Nov. 7, 2015); see generally The Shaolin Temple, IMDB, available at http://www.imdb.com/title/tt0079891/ (last visited Nov. 7, 2015). 
religious themes are more likely denied approval by the Chinese censors. Conversely, films that deal with the more traditional Chinese religions, such as Confucianism, Daoism, or Buddhism, however, are likely acceptable.

Films that are too gory or violent are also likely to face rejection from the Chinese censors; however, the rejection of this content begs the question of where the line between acceptable gore and violence is. For example, Django Unchained was not only accepted by the censors after the director toned down the film's violence and nudity, but even began to screen before being abruptly yanked from theatres only minutes into its first screening. ${ }^{141}$ Anyone who has seen the film is aware of its somewhat over-the-top displays of violence, featuring dozens of killings where "blood explodes off the bodies in little bursts of red," and yet, it initially passed the censors with relatively small adjustments. ${ }^{142}$ Inevitably, there is a line between acceptable and unacceptable levels of violence, but that line is not always so clear.

A time travel theme could also upset the censors. ${ }^{143}$ On its face, this seems to be a rather silly criteria to ban but is actually taken quite seriously in China. Chinese officials view time travel as being disrespectful of history. ${ }^{144}$ However, the implications of time traveling characters are readily apparent once one thinks about them. Traveling in time means escaping from the current era and, in China, this means escaping from the Communist Party-dominated state. ${ }^{145}$ Traveling back in time poses an even greater risk should the protagonist seek to change history. This particular sub-genre of science fiction runs the risk of being a vehicle to criticize the Chinese state. It is not surprising that the censors and government are unwilling to allow this sort of storyline into Chinese theatres. While it is true that China produces its own historical films, for example, about the Nanjing Massacre of World War II, ${ }^{146}$ other historical

141. See Brody, supra note 109; see also DeHart, supra note 110.

142. David Denby, "Django Unchained": Put-on, Revenge, and the Aesthetics of Trash, NEw YORKER (Jan. 22, 2013), available at http://www.newyorker.com/culture/culturedesk/django-unchained-put-on-revenge-and-the-aesthetics-of-trash (last visited Nov. 7, 2015).

143. See Richard Brody, China Bans Time Travel, NEW YORKER (Apr. 8, 2011), available at http://www.newyorker.com/culture/richard-brody/china-bans-time-travel (last visited Nov. 7, 2015).

144. Id.

145. Id.

146. See, e.g., Top 10 Nanjing Massacre Movies, CHINA WHISPERER (Dec. 4, 2012), available at http://www.chinawhisper.com/top-10-nanjing-massacre-movies/ (last visited Nov. 7, 2015). 
topics are still not permitted in Chinese cinema, such as any negative portrayal of Mao Zedong and his role in the Cultural Revolution. ${ }^{147}$ Allowing films about time travel, then, could subtly show the Chinese Communist Party in a negative light.

Essentially, it does not seem possible to contrive a hard and fast list of factors that will lead to the censors' rejection. Even though SARFT has released a fairly long list of the type of content that is impermissible or requires cutting or alteration, their descriptions are broad and rather vague, offering overarching categories with no concrete details. While this lack of concrete detail may not offer a set of definitive instructions for Hollywood studios on questionable content, the SARFT guidelines at least identify areas where studios know they will have to tread carefully, applying these guidelines in the context of experiences with previous films. The studios are accustomed to risk - there is never a guarantee that any film will find favor with an audience, even if the film is the sequel to a major blockbuster. Therefore, it would not be a tough step for studios to use these guidelines to prepare its products for Chinese approval.

\section{B. Arbitrary}

The inherent arbitrariness of the censorship regime is another problem with the current system that beleaguers Hollywood studios. Studios are left to rely on a list of vague proscriptions and examples from past films. Examples such as Django Unchained, Outcast, and Hunger Games: Mockingjay-Part 1 are prime illustrations of the Chinese censor's fickle nature. ${ }^{148}$ Even gaining approval from the censors is not enough to guarantee a smooth screening in Chinese theatres and, often times, the reasons for the backpedaling are unclear, allowing for speculation to run wild as to the censors' change of heart. ${ }^{149}$ Of course, much of the underlying reasoning for the system's arbitrariness is the government's desire to keeps its censorship criteria flexible and able to respond to the society's shifting and the "perceived danger of the day." 150 While this arbitrariness may very well suit the needs and goals of the Chinese government, the fact still remains that this flexibility comes

147. Lilian Lin, Chinese Director Fires Back at Oliver Stone, Wall St. J. (Apr. 22, 2014. 7:13 PM), available at http://blogs.wsj.com/chinarealtime/2014/04/22/chinesedirector-ning-haofires-back-at-oliver-stone/ (last visited Nov. 7, 2015).

148. See DeHart, supra note 110; see also Verrier \& Makinen, supra note 115; FlorCruz, supra note 137.

149. See DeHart, supra note 110; see also Verrier \& Makinen, supra note 115; FlorCruz, supra note 137.

150. Ya Qin, supra note 28, at 7. 
across as arbitrariness to the studios that are subject to the changing tides of Chinese censorship.

\section{Lack of Transparency}

A third prominent issue with the current system is its complete lack of transparency. Despite the 2012 agreement between Chinese Vice President Xi Jinping and U.S. Vice President Joe Biden and the expectation that it would improve system's transparency, these hopes have not been fully met. ${ }^{151}$ Not only did the agreement increase the number of revenue-sharing slots available for foreign films each year, it also promised a new national distributor that would be able to compete with the state-owned China Film Group Corporation in a way that the much more limited Huaxia Film Distribution Co. could not. ${ }^{152}$ While the import quota has been expanded, it was not until just recently that China began to discuss the possibility of a new national distributor. ${ }^{153}$ It is still unclear if this second distributor will actually compete against the existing China Film Group or if the two groups will divide the existing import quota between themselves. ${ }^{154}$

The agreement also stated that the transparency of the system would be improved by allowing the foreign rights owners access to censorship decisions - which they are not currently given - and to the terms of deals struck between the import companies, distributors, and exhibitors. ${ }^{155}$ The idea is that the studios would be able to negotiate directly with the censors when an issue arises to address problems or substitute alternative films under the terms of their previously signed import agreements. ${ }^{156}$ The experiences of several recent films, however, seem to indicate that this new level of transparency is not implemented. ${ }^{157}$

China's State Secrets Law and its recent revisions may also contribute to the system's lack of transparency. If the State should decide that its censorship decisions impact China's national interests and therefore become classified as a state secret, the various SOEs that

151. See Frater, supra note 85.

152. Id.

153. Patrick Frater, China Expected to Confirm Second Theatrical Distribution License, VARIETY (March 23, 2014, 4:31 PM), available at http://variety.com/2014/biz/asia/chinaexpected-to-confirm-second-theatrical-distribution-license-exclusive-1201143916/ (last visited Nov. 7, 2015).

154. $I d$.

155. $I d$.

156. $I d$.

157. See DeHart, supra note 110; Verrier \& Makinen, supra note 115; FlorCruz, supra note 137 . 
contract directly with the studios would not be permitted to divulge the reasons a film failed the censors. ${ }^{158}$ Censorship decisions are also considered a part of major policy decisions, as they serve to regulate the content of all media forms that reach Chinese citizens, including the film medium. ${ }^{159}$ SOEs, understanding that the State Secrets Law may very well apply to them, may not wish to risk divulging censorship decisions to the studios, instead simply citing a vague issue with the censors when seeking to breach their contracts with the studios. To make matters more complex, depending on the seriousness of the breach of a state secret, the consequences could either fall under administrative punishments or criminal punishments, leaving the spectrum of possible punishments very broad. ${ }^{160}$ Also, the law's retroactive nature has not increased the transparency of censorship decisions. ${ }^{161}$

\section{Failure to Pay}

Another issue with the current system that arose in the wake of the 2012 Xi-Biden agreement was China's attempt to impose a Value Added Tax ("VAT") to the studios' $25 \%$ revenue share of the Chinese box office. ${ }^{162}$ Many studios, trying to avoid a dangerous precedent, refused to accept payment rather than allow the VAT to take a chunk of the studio's earnings. ${ }^{163}$ This attempted imposition of a VAT was especially frustrating to U.S. studios, who already deal with the rather mercurial moods of Chinese officials when it comes to foreign films' access to the Chinese market, given the promised $25 \%$ cut of the box office profits had been a relatively recent concession on the part of China. ${ }^{164}$ While it appears that the dispute was resolved because the studios will not be responsible for the VAT, the incident just serves as another illustration of the problems in the current system. ${ }^{165}$

158. See generally Law on Guarding State Secrets, supra note 58, arts. 1, 2.

159. See id. art. 8.

160. Id. art.11.

161. See State Secrets: China's Legal Labyrinth, supra note 69.

162. Rachel Abrams \& Andrew Stewart, Hollywood Studios Denied Payments from China, VARIETY (July 29, 2013, 03:35 PM), available at https://variety.com/2013/film/news/hollywood-studios-denied-payments-from-china1200503744/ (last visited Nov. 7, 2015).

163. Id.

164. See id.

165. See Michael Cieply \& Brooks Barnes, Dispute Over Value-Added Tax on Movie Tickets in China Appears Near End, N.Y. TIMES (Aug. 7, 2013), available at http://www.nytimes.com/2013/08/08/business/media/dispute-over-value-added-tax-onmovie-tickets-in-china-appears-near-end.html?pagewanted $=$ all\&_r $=0$ (last visited Nov. 7, 2015). 


\section{WTO RULING \& IMPACT-SHOULD WE PUSH FOR CHINA'S COMPLIANCE?}

On January 19, 2010, the WTO's Appellate Body's report, ChinaMeasures Affecting Trading Rights and Distribution Services for Certain Publications and Audiovisual Entertainment Products ("ChinaAudiovisual Services"), became formally accepted by the WTO's Dispute Settlement Body ("DSB"). ${ }^{166}$ The Appellate Body, and the accompanying panel report, found that China was in violation of the WTO law by failing to allow non-SOEs to import cultural products, such as books, magazines, newspapers, and films. ${ }^{167}$ China was also found in violation due to its prohibition on foreign entities from engaging in distribution services for cultural products, such as film, in China. ${ }^{168}$ The WTO found China's restrictions on the right to import inconsistent with its commitments to liberalize trading rights under its Accession Protocol, ${ }^{169}$ that its restrictions on distribution services are inconsistent with its obligations under the General Agreement on Trade in Services ("GATS"), and that its restrictions on distribution services are also inconsistent with the General Agreement on Tariffs and Trade ("GATT"). ${ }^{170}$ In this ruling, the WTO judges also refused to accept China's defense that its restrictions on trading rights are necessary for the operation of its censorship regime, which should be justified under the "public morals" exception of the GATT. ${ }^{171}$ The WTO granted China until March 19, 2011 to comply with its rulings, but China has failed to fully comply. ${ }^{172}$

The GATT's fundamental principles are non-discrimination, market access and transparency and it contains binding commitments on tariffs and quotas for goods. ${ }^{173}$ The GATT is a powerful tool to restrict members' censorship efforts, especially under Article XI, which states that:

166. Liying Zhang \& Xiaoyu Hu, Liberalization of Trade and Domestic Control on Cultural Products: The Application of Public Morals Exception in China-Audiovisual Services, 45 REVUE JURIDIQUE THÉMIS 403, 407 (2011).

167. Ya Qin, supra note 28, at 1-2.

168. Id. at 2.

169. Protocols of Accession for New Members Since 1995, Including Commitments in Goods and Services, WORLD TRADE ORG. (Apr. 26, 2015), available at https://www.wto.org/english/thewto_e/acc_e/completeacc_e.htm\#list (last visited Nov. 7, 2015) (affirming China's membership to the WTO).

170. Id.

171. Id.

172. Id.

173. Ting, supra note 40, at 293. 
$[\mathrm{N}] \mathrm{o}$ prohibitions or restrictions other than duties, taxes or other charges, whether made effective through quotas, import or export licenses or other measures, shall be instituted or maintained by any contracting party on the importation of any product of the territory of any other contracting party or on the exportation or sale for export of any product destined for the territory of any other contracting party. ${ }^{174}$

In short, this article proscribes the use of quotas and bans on the trade of goods. ${ }^{175}$ Article XX, however, provides a series of exceptions to the general GATT commitments. ${ }^{176}$ The one most pertinent to China's case is the exception laid out in Article $\mathrm{XX}(\mathrm{a})$, the public morals exception. ${ }^{177}$ Using this exception, China could justify its film censorship and limits on importation and distribution.

The problem China encountered in trying to use the public morals exception comes from its original accession to the WTO in December $2001{ }^{178}$ In its accession commitments, China agreed that all enterprises in China, as well as all foreign individuals and enterprises, including those not invested or registered in China, would have the right to import and export goods throughout the country's customs territory within three years, except for a list of products reserved for trading by designated SOEs. ${ }^{179}$ China listed these reserved products in Annex 2A of its Accession Protocol, but amongst the eighty-four products for importation and 134 products for exportation, cultural or information products are completely absent. ${ }^{180}$ This absence did not help China's case when the WTO Panel sought to determine whether or not China satisfied the public morals exception in Article XX(a) of the GATT. ${ }^{181}$ The Panel ultimately concluded that the measure prohibiting all private domestic and foreign entities from importing cultural products was too severely restrictive for these measures to be necessary to protect public morals and that China needed to grant the right to import cultural products in accordance with its trading rights commitments. ${ }^{182}$

While full compliance with the WTO ruling would allow foreign

174. General Agreement on Tariffs and Trade art. 11, Oct. 30, 1947, 61 Stat. A-11, 55

U.N.T.S. 194 [hereinafter GATT].

175. Ting, supra note 40, at 293.

176. Id.

177. GATT, supra note 174 , art. XX(a).

178. Ya Qin, supra note 28 , at 5.

179. Id.

180. Id.

181. Id. at 9 .

182. Id. at 11,13 . 
companies to sell their products directly to Chinese consumers, and therefore allow studios greater access to Chinese theatres, it would require China to alter the way it conducts censorship on imports. ${ }^{183}$ The Panel pushed for what it saw as a "reasonably available alternative" to the system, which had been proposed by the U.S. ${ }^{184}$ This suggestion would give the Chinese government sole responsibility for content review, rather than allowing SOEs to review such content. ${ }^{185}$ Under the current system, the individual SOEs perform content review on the films they import based on their own internal review process. ${ }^{186}$ In some ways, this is a fairly efficient system from the Chinese government's perspective, as it is able to delegate the task of censoring imported films to trustworthy government controlled SOEs. ${ }^{187}$ However, centralizing this system could have some negative impacts on Hollywood's access to the Chinese market.

Currently, the SOEs involved in importing films enjoy a fair amount of discretion when it comes to interpreting the vaguely worded guidelines issued by SARFT. ${ }^{188}$ On the one hand, these SOEs have a financial incentive to interpret these guidelines as broadly as possible as it is in their economic interest to bring in films that are likely to bring in the most revenue. ${ }^{189}$ However, centralizing the censorship mechanism could then have a cooling effect and result in much more cautious applications of the censorship criteria. It would result in a much more rigorous and strict screening process, making the barriers Hollywood films face even higher than they are now. ${ }^{190}$ After all, government bureaucrats are not affected by the profit motive and would instead be inclined towards behavior that would ensure their continued existence. Also, if the Chinese government switches over to a centralized review system, it is possible that it will also impose a legal duty on the private importers to self-censor and "when private businesses are required by law to practice self-censorship, they tend to err on the side of caution and over-censor content that does not clearly violate the rules." 191 Ultimately China is under no obligation to

183. Ya Qin, supra note 28, at 15.

184. Id. at 11.

185. Id. at 12 .

186. Id. at 16 (elaborating that SOE approval does not necessarily mean a higher authority will not step in and reverse the SOEs decision, as has likely happened in the cases of many Hollywood films in China).

187. Id. at 18.

188. Ya Qin, supra note 28, at 19.

189. See id.

190. See id.

191. Id. at 20. 
fill even its current quota of foreign films and complying with the WTO ruling could result in fewer foreign films entering the Chinese market.

\section{RECOMMENDATIONS}

This final section will be dedicated to outlining possible solutions to some of the problems that plague the current censorship and importation regime under which Hollywood films are screened in China. First, it will examine liquidated damages clauses under Chinese contract law. Next, this section will examine joint productions between Hollywood and Chinese studios. Thirdly, this section will examine the feasibility of Hollywood studios planning for film modifications prior to submitting them to the Chinese censors. Finally, this section examines the various ways Hollywood studios should lobby the U.S. government to negotiate with China on their behalf.

\section{A. Contractual Enforcement/Liquidated Damages}

There are relatively simple solutions to situations where films are given the green light to screen and then later delayed or pulled from theatres. Hollywood studios, when entering into contracts with SOEs that handle the importation of foreign films, should build a liquidated damages clause into their contracts in the event that the contract is breached via approval recall. A liquidated damages clause would not only ensure that the studio insulates itself from a large loss of revenue, but would also give the Chinese SOEs better incentive to carefully consider what the film may need to alter or eliminate from the outset, rather than subject the studio to later, unanticipated alteration requirements. ${ }^{192}$

The Contract Law of the People's Republic of China ${ }^{193}$ ("Contract Law") itself has an entire section dedicated to liability for the breach of contract, stating at its outset that "[e]ither party that fails to perform its obligations under to contract or fails to perform them as contracted shall bear the liability for breach of contract by continuing to perform the obligations, taking remedial measures, or compensating for losses." 194

192. See, e.g., DeHart, supra note 110 (stating Django Unchained producers had already made minor alterations to the film prior to its acceptance by the Chinese censors only to be pulled minutes into its first screening and subjected to further alterations before it was rereleased).

193. For the purposes of this note, I am assuming that these contracts are entered into under Chinese law with Chinese courts as the chosen forum, as well as that the contracts are not conditioned on approval by the censors.

194. Zhonghua Renmin Gongheguo Hetong Fa (中华人民共和国合同法) [Contract 
The Contract Law also has a specific section allowing for liquidated damages specifically, stating that " $\mathrm{t}]$ he parties may stipulate that in case of breach of contract by either party a certain amount of penalty shall be paid to the other party according to the seriousness of the breach, and may also stipulate the method for calculating the sum of compensation for losses caused by the breach of contract."195 The studios should build these liquidated damages clauses into their Chinese contracts based on a percentage of calculated lost revenue.

The studios can also point to the fact that they have been subject to lawsuits from Chinese companies in the past, such as the lawsuit brought by the Chinese tourism company over Paramount's alleged breach of contract for the film Transformers: Age of Extinction. ${ }^{196}$ In this dispute, the Wulong Krast Tourism Group claims that Paramount Studios breached their contract by not making it clear that the scenic scenes featured in Transformers: Age of Extinction were shot in the Wulong Scenic Area, which the Wulong Krast manages, because the studio failed to include the firm's logo in the shot. ${ }^{197}$ The tourism firm demanded that the studio show their logo in all DVDs, TV, and digital platforms on which the movie will be shown, as well as a return of the 4.8 million yuan they made in contract payments. ${ }^{198}$ The tourism firm also requested 12 million yuan in expected profit losses as it was required to shut the scenic spot down for several days due to filming. ${ }^{199}$ If the studios are going to be vulnerable to law suits from the various Chinese companies they contract with in the process of readying their film for a Chinese audience on top of the well-known vicissitudes of China's censorship regime, building in some semblance of protection into their contracts with the SOE is a simple but effective measure that should be taken.

\section{B. Joint Productions}

Hollywood studios can reduce their exposure to the problems with the current system by entering into joint productions with Chinese studios or companies. Such ventures would be governed by the China Film CoProduction Corporation ("CFCC"), which is a special organization solely authorized by SARFT to administer affairs relating to Chinese-foreign

Law] (promulgated by the Nat'l People's Cong. Standing Comm., Mar. 15, 1999, effective Oct. 1, 1999), art. 107 [hereinafter Contract Law].

195. Id. art. 114.

196. See Jin \& Yin, supra note 126.

197. See Goh, supra note 131.

198. Id.

199. Id. 
film co-productions. ${ }^{200}$ CFCC assesses and approves international coproduction applications, conducts reviews of completed co-production films, supervises the performance of co-production agreements between the co-producing parties, provides relevant services, and assists in negotiations of governmental agreement on film co-production between China and other countries. ${ }^{201}$ CFCC also handles much of the logistical concerns that arise when filming in China, such as facilitating entry visas for foreign crews participating in co-productions. ${ }^{202}$

CFCC lists the particulars of its detailed, three part process that must be followed when applying for a co-production. ${ }^{203}$ These guidelines put the burden of approval seeking on the co-production's domestic partner and it is done under a Domestic Film Review and Approval Form, meaning that the film will be able to be registered as a domestic film and therefore not subject to the foreign film import quota. ${ }^{204}$ While coproductions will still be subject to the Chinese censors, it will undergo review as a domestic Chinese film and it is likely that the Chinese production partner will be able to give the foreign production partner a better sense of what will pass and what will not pass the Chinese censors.

Formally, co-productions are defined as films "which are jointly produced by co-financing, assisting or commissioning in and/or outside of China between the Chinese film producers (hereinafter referred to as the Chinese Side) who have obtained 'The Film Production Permit' or 'The Film Production Permit (Single Film)' in a lawful manner and the overseas film producers (hereinafter referred to as the Foreign Side)."205 These co-productions can take one of three forms:

1. Co-production, referring to a film which is co-financed (including funds, labor or in kind) and jointly produced by the Chinese and Foreign Sides, with sharing of benefits and risks; 2. Assisted Production, referring to a film which is solely financed by the Foreign Side and shot in China with paid assistance by the Chinese Side by providing

200. About China Film Co-Production Corporation, China Film Co-Production CORP., available at http://www.cfcc-film.com.cn/introeg/intro.html (last visited Nov. 7, 2015).

201. Id.

202. Id.

203. See Guidelines Film Co-Production Corporation, China Film Co-Production CORP., available at http://www.cfcc-film.com.cn/introeg/busine.html (last visited Nov. 7, 2015).

204. See Id.

205. Zhongwai Hezuo Shezhi Dianying Pian Guanli Guiding (中外合作摄制电影片管 理规定) [Administrative Regulations on Sino-Foreign Film Co-Production] (promulgated by the St. Admin. for Radio, Film and Television, July 6, 2004, effective Aug. 10, 2004), art. II. 
equipment, facilities, locations, labor and etc.; and 3. Commissioned Production, referring to a film which is commissioned by the Foreign Side to be made in China by the Chinese Side. ${ }^{206}$

Entering into a co-production with a Chinese partner actually leaves the Hollywood studio with a wide range of production options. This arrangement also does not limit Hollywood studios to filming in China only, as The Stipulation of Administration on Chinese-Foreign Film Coproduction ("Stipulation"), the main policy governing these coproductions, allows for "films in and/or outside China."207 While the Stipulation does restrict the composition of the total cast, stating that it can only be two-thirds non-Chinese actors, failing to indicate the types of roles the Chinese and non-Chinese actors must fill, and while it does mandate that a Putonghua ${ }^{208}$ version of the film be made, these extra requirements may very well be worth it to Hollywood studios in the long run, since it allows them to bypass the import quota and possibly have a better, insider's view towards the censorship regime. It would also give the studios an actual, physical presence in China, which could then lead to a better relationship with the relevant governmental bodies at play in China's film industry.

Recently, one potential joint venture has been getting some journalistic attention. Warner Bros. Studio is currently in talks with China Media Capital about forming a joint venture which will aim to produce local-language films. ${ }^{209}$ Should this partnership go through, it would provide for a longer-standing relationship between the two parties, one which would seek to produce a number of films, as opposed to a relationship formed to produce simply one film. ${ }^{210}$ Other studios should seek to engage local studios and investment companies in the way Warner Bros. is engaging with China Media Capital in order to fully capitalize not just on China's market for foreign films, but the growing market for locally produced films as well.

\section{Planning for Modifications}

Another relatively simple step Hollywood studios could take in

206. Id. art. V.

207. Id. art. III.

208. The official language of China.

209. Ben Fritz \& Shalini Ramachandran, Warner Bros. in Talks to Make Movies in China, WALL ST. J. (Aug. 25, 2015, 12:01 AM), available at http://www.wsj.com/articles/warner-bros-in-talks-to-make-movies-in-china-1440475260 (last visited Nov. 7, 2015).

210. See id. 
trying to mitigate the effects of China's current censorship regime is to plan for modifications before the film even goes up for approval in China. Of course, to plan for appropriate modifications the studios and producers will need to gain a better understanding of the current climate and culture in China. Pre-emptive adjustments have appeared to pay off in several cases already, such as with the film World War Z.211 Iron Man 3 is another great illustration of pre-emptive modifications leading to a successful run in China. ${ }^{212}$ Iron Man 3 is also a prime example of a Hollywood studio being prepared to pay out a little more to produce a version of its film that is geared towards China to reap the benefits of having it screen in the country that constitutes the second largest market for film in the world.

Hollywood studios should even consider sprinkling a few Chinese product placements into their film's Chinese version or giving small, bit parts to famous Chinese actors or actresses. Again, this sort of tactic worked well for Iron Man 3 in terms of getting it approved by the Chinese censors. ${ }^{213}$ In fact, this tactic worked so well for Marvel studios in Iron Man 3 that it was used again in X-Men: Days of Future Past, which casted famous Chinese actress Fan Bingbing as Blink, in the character's debut appearance in the $X$-Men films. ${ }^{214}$ Casting popular Chinese actors and actresses also has the potential benefit of not just appeasing the censors, but of appealing more to the film's Chinese audience as well. There is a growing acceptance of Asian actors performing as Asians, as evidenced by films such as X-Men: Days of Future Past, and this is a trend Hollywood studios would be wise to take advantage of. If possible, perhaps studios could even keep a collection of stock footage-which is known to be acceptable to the Chinese censors-from China that can be inserted into films aimed at the Chinese market.

\section{Lobbying for Negotiations}

A final possible solution for Hollywood studios to consider is lobbying the government to continue its negotiations with China, particularly in terms of getting China to conform to the terms of agreements already made. The $2012 \mathrm{Xi}$-Biden agreement was a good start, particularly in light of the WTO ruling against China, but

211. See Shaw, supra note 99.

212. See Acuna, supra note 5.

213. See Lau, supra note 6.

214. Xinhua, Face of Future Past: Fan Bingbing Proud to be X-Men's Blink, WanT China Times (May 23, 2014, 11:48 AM), available at http://www.wantchinatimes.com/newssubclass-cnt.aspx?id=20140523000058\&cid=1104 (last visited Nov. 7, 2015). 
Hollywood studios should lobby for more. ${ }^{215}$ Studios should urge the government to take the ground that was gained in these negotiations and use it to keep pushing for continued improvements to the system, such as increased transparency. ${ }^{216}$ Hollywood studios and the Motion Picture Association of America ("MPAA"), a major representative of Hollywood studios, should also continue to stress to lawmakers that China is an important and fully developed market for U.S. films, a market that promises a lucrative revenue stream, and that the U.S. government needs to keep putting pressure on China to continue opening up. ${ }^{217}$ This would constitute a win-win situation for both China's government and the U.S. studios. China's agreement to increase the number of revenue-sharing films imported each year was certainly a victory, but there is more that can be done.

Opening up the Chinese market even further could even produce positive impacts that go beyond revenue. As MPAA Chairman and CEO, Senator Chris Dodd has said, "Sino-foreign and other international coproductions provide an opportunity for creators to view their craft through scopes that they might not otherwise consider, boosting creativity, technological advancements and the viewer experience." ${ }^{218}$ It would not be a huge leap to extrapolate this understanding out for an increased understanding between the U.S. and China as a whole. The potential to use the U.S. film industry as a vehicle for cultural export and a form of "soft power," as well as a means for greater understanding on both sides, is just one of the many reasons Hollywood studios can bring to the table when lobbying the U.S. government to increase its negotiations with China on their behalf.

215. See Frater, supra note 151.

216. Id.

217. Id.

218. 4th MPA-China Film Screenings Underscores Expansive Partnership Between U.S. \& Chinese Motion Picture Industries, Motion Picture Ass'N AM. (Nov. 3, 2014), available at http://www.mpaa.org/wp-content/uploads/2014/11/4th-MPA-CHINA-FILMSCREENINGS-UNDERSCORES-EXPANSIVE-PARTNERSHIP-BETWEEN-U.S.CHINESE-MOTION-PICTURE-INDUSTRIES.pdf (last visited Nov. 7, 2015). 